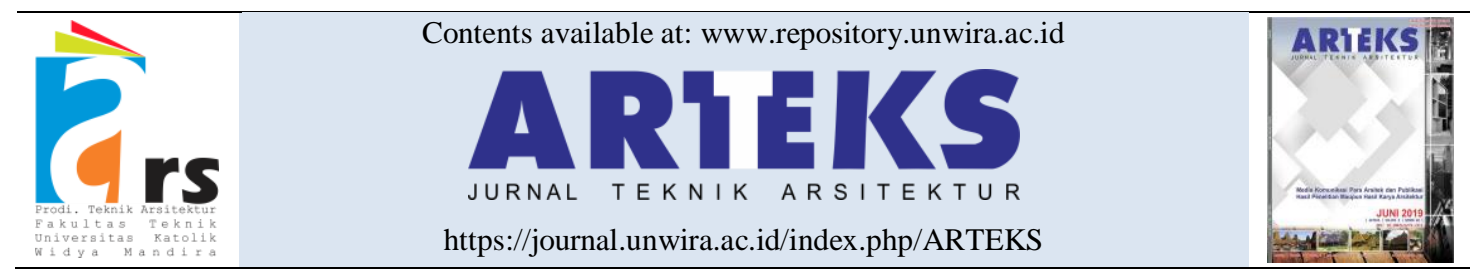

Research paper

doi: 10.30822/arteks.v5i3.609

\title{
The role and meaning of fireplace in Karangtengah Hamlet Settlement, Banjarnegara: A study of the spatial pattern of pawon and kindship
}

\author{
Yohanes Basuki Dwisusanto $^{1 *(\mathbb{D})}$, Hermawan ${ }^{2}$ \\ ${ }^{1}$ Architecture Study Program, Faculty of Engineering, \\ Universitas Katolik Parahyangan, Jl. Ciumbuleuit no. 94, Bandung, Indonesia \\ ${ }^{2}$ Universitas Sains Al-Qur'an, Indonesia
}

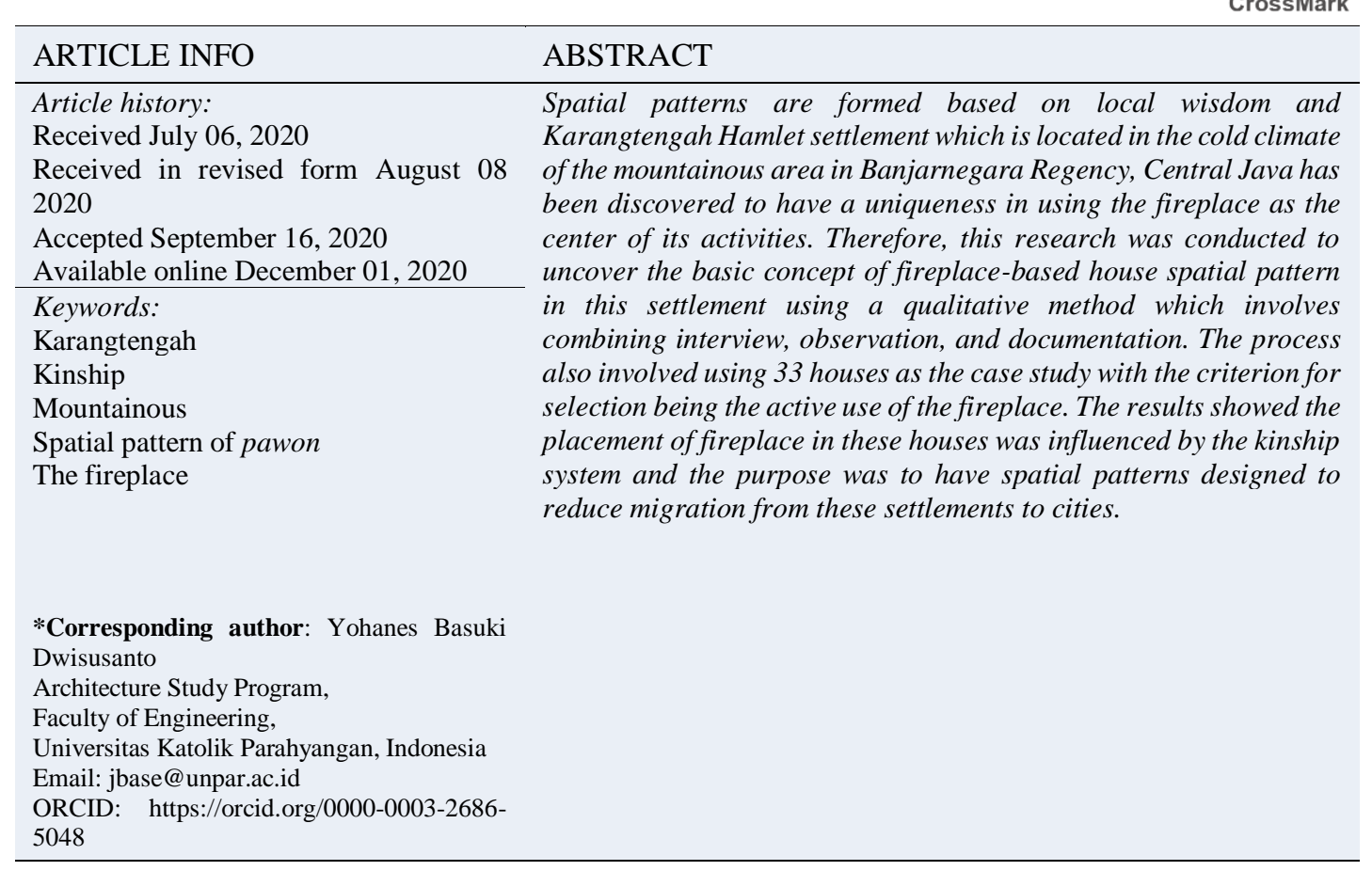

\section{Introduction}

Regional design principles are formulated by researching the spatial patterns associated with the activity of residents. This means the architecture and spatial design of a region are two closely related sciences (Sudradjat 2020). Moreover, the science associated with the planning of a place is dependent on the architectural landscape, urban design and planning, and the architecture (Kullmann 2016). Optimal area design is, therefore, achievable through the selection of an appropriate strategy.
There is a need to search for adequate spatial patterns in creating efficient spatial planning. A residential study in the Netherlands found the implementation of an adequate spatial pattern strategy through functional efficiency in spatial placement was able to create multilateral relationships between spaces. The focus was on analyzing and comparing the floor plans for the housing and apartments in the country (Hosseini Raviz et al. 2015). This is important because trends in spatial development and organization are usually used in analyzing the spatial patterns of a particular area. This was observed in the study on 
the relationship between the spatial and residents in the residential houses of the Mekong River. The results showed the spatial pattern was modified at the back of the house as well as room size, residence size, and occupant status due to socio-cultural factors (Thanousorn and Oikawa 2010).

The religious aspect is another factor influencing spatial patterns. The research by Kathmandu showed swastika which is a traditional pattern associated with Hinduism and Buddhism was applied to regional spatial patterns. The back and front yards of the rectangular house were analyzed and the size of the residence was determined with the area of the front yard and its layout using a swastika pattern. The analysis also showed swastika is used in determining the architectural configuration of Buddhist monasteries (Pant and Funo 2004). Another research showed the spatial pattern of Thai Islamic residences is a reflection of the dialogical relationship between socio-cultural and temporal dimensions. The way of life of Muslim residents influences a lot of meaning contained in the traditional Thai houses (Wongphyat 2009).

The spatial pattern also changes according to social and economic functions. A study on an apartment in Osijek, Croatia showed the existence of five innovative spatial patterns and differences based on the function of the apartments organized by space and zone, direct and indirect communication between spaces, appearance, and integration of spatial functions, as well as the growth and decline in the net area of the room (Brkanić, Stober, and Mihić 2018).

Socio-culturalism is an influencing factor in architectural science as observed with the effect of socio-culture, both physical and spiritual, on architecture (Subroto 2019). The aspects felt physically and spiritually but not realizable on the site materials are called genius loci or local genius which is defined as an intangible character from a place. It is also explained as the spirit of a place which is not formed but happens automatically (Markevičienè 2012).

Socio-culture is also closely related to the environment and both factors are usually analyzed to produce a humanist residential design. Environmental assessment provides solutions to several problems in architecture, including climate, lighting, view, family relations, lifestyle, socio-cultural needs, and community views (Alkhansari 2015). This means spatial patterns are influenced by the social aspect, culture, religion, and economy. Meanwhile, local wisdom or genius loci is the basis for creating spatial patterns with the research method focused on analyzing indoor and outdoor room plans.

The characteristics of vernacular architecture are interesting to be studied and are also useful as the basis for sustainable architectural design. The research conducted on Sana'a architecture showed it contains cultural aspects such as community activity, privacy, and views and also has the ability to cope with the climate. Moreover, the relationship between Form and Space was also associated with climate and function and narrow vertical shape was found to be better than an elongated shape. The results also showed the best bedroom placement is in the southern part of the house, the main activity space is better placed on a higher floor to have access to the sun, and the rooms are to be placed based on daily routine activities according to the path of the sun. This means it is possible to use Sana'a architecture as a reference in designing modern houses (Al-Sallal 2001).

Different spatial patterns are created based on regional characteristics. For example, mountainous communities usually have heaters as observed in the use of wood fuel to provide heats in traditional Hanoks homes. The traditional heater is known as Gudeul and maintained according to the vernacular architecture despite its more disturbing effects on the senses of touch and smell compared to its warming function (Yun 2016). Moreover, cultural, climatic, and topographic conditions are elements of discussion in the spatial pattern used in determining the boundary and shape of a settlement (Zappulla, Suau, and Fikfak 2014).

It is important to show the spatial patterns in vernacular houses because they are believed to contain deep meaning in people's lives. This is observed in the mountainous community of Karangtengah Hamlet, Banjarnegara, Central Java where the fireplace is the center of their livelihood activities from functional, social, and symbolic aspects. The spatial pattern of the houses in the settlement seems to be influenced by fireplaces. Therefore, this research was conducted to determine the concepts used in forming the spatial pattern of the fireplace-based residential houses in mountainous areas. 


\section{Method}

A case study qualitative research method was used to explore the meaning of the phenomena in this study (Creswell and Poth 2017). The focus of this research was on the phenomenon in Karangtengah houses which involves using the fireplace as a center of activity affecting spatial patterns in mountainous areas. This study made use of 33 houses as a case study and Karangtengah was found to be included in the Dieng Mountains area with an altitude of 1,663 $\mathrm{m}$ above sea level. It is in Batur Sub-district, Banjarnegara Regency which is located close to the largest lake, Merdada, in the regency and also to the Dieng tourist complex. The topographical condition of the mountains is fairly steep slope while the agricultural area is made with a terracing system and it requires the residents to walk for approximately half an hour from their houses. Moreover, the houses are grouped according to the patterns of the mountains as observed in the top view image presented in figure 1 .

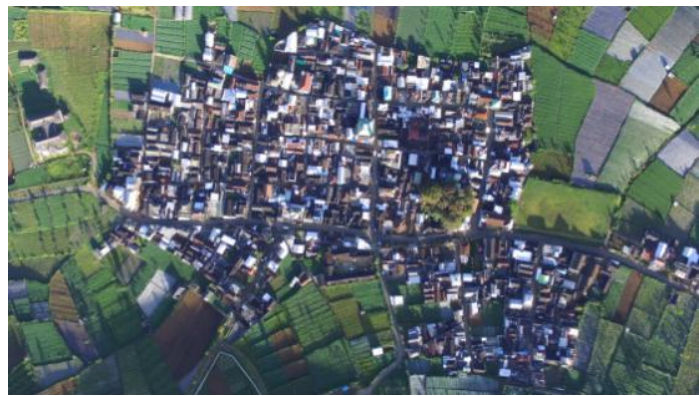

Figure 1. Karangtengah Hamlet

\section{Result and discussion}

Four types of fireplaces were discovered in Karangtengah hamlet and they include stone, gas, braziers, and drum furnaces. Stone furnaces are made of stone with wood, corn husks, coconut shells, and rice husks used as fuel but the wood was found to be the most dominant due to its availability. The furnace is usually placed in the pawon or kitchen and the fire is mostly maintained using a semprong which is a piece of bamboo with the length found to be approximately $30-50 \mathrm{~cm}$ without ros or bamboo divider. The semprong is used by blowing wind through a hole in the bamboo. Meanwhile, the stone furnace, shown in figure 2 , is considered to be the most comfortable heater.

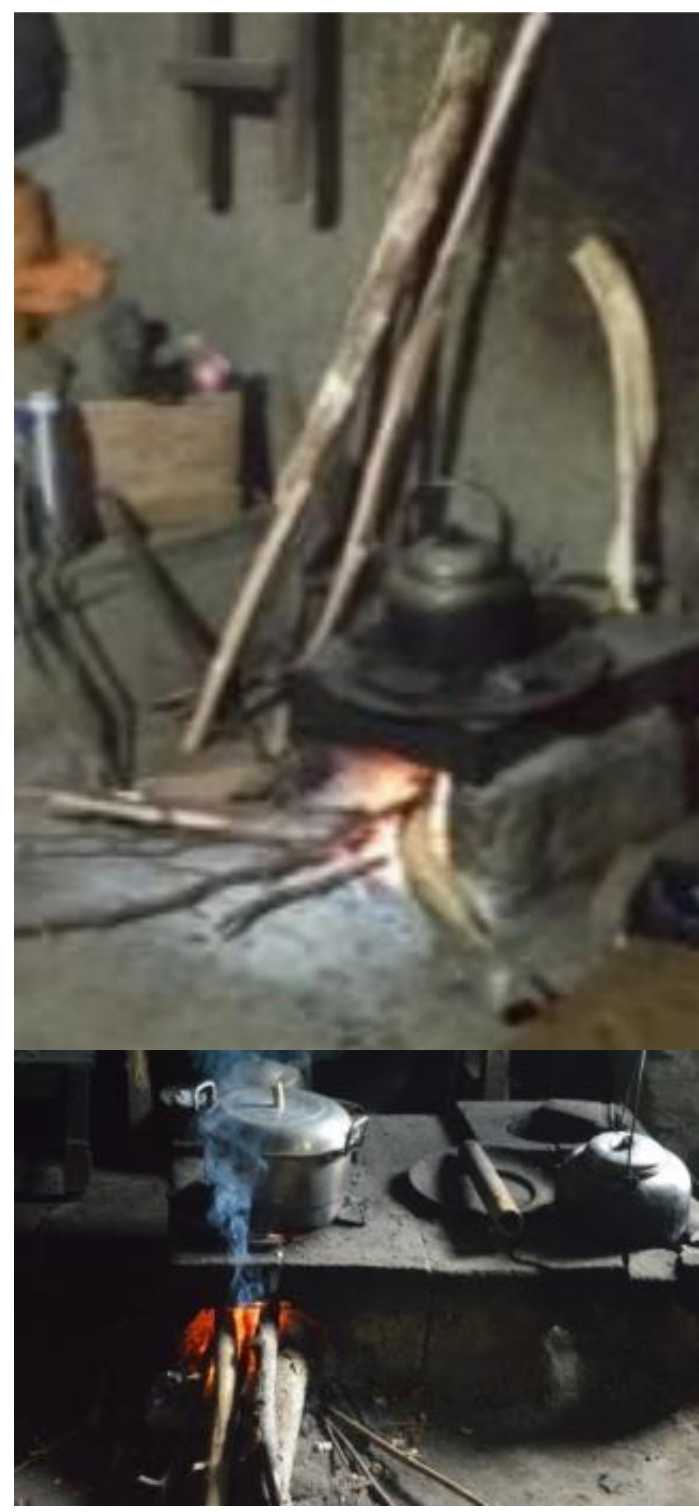

Figure 2. Types of fireplaces in Karangtengah Hamlet

The second type is a gas furnace and observed to be used by approximately $40 \%$ of the population. Some local residents think stone furnace causes negative impacts and switch to natural gas heating devices because it is considered cleaner, simpler, and can be moved easily. The production of this type of furnace requires special expertise and this limits the number of residents using it. The furnace cannot be used for cooking and this means it is only used for heating. The third type is brazier which is a small fire holder considered easier to move around due to its size and used in houses without 
stone or gas furnace. It uses charcoal or burned wood as fuel and often placed in the kitchen (pawon), living room, family room, and bedroom. The furnace is usually used by residents to warm up after watching television. Meanwhile, some houses use both stone and brazier furnaces in heating. The last type is the drum furnace which is usually made outside the room during the khataman and commemoration of the Prophet's birthday. It is also used as a fireplace or genen at the regional level and instead of using drums, burning tires, wood, or other combustible items are also used. The gas and charcoal furnaces are, therefore, shown in figure 3.
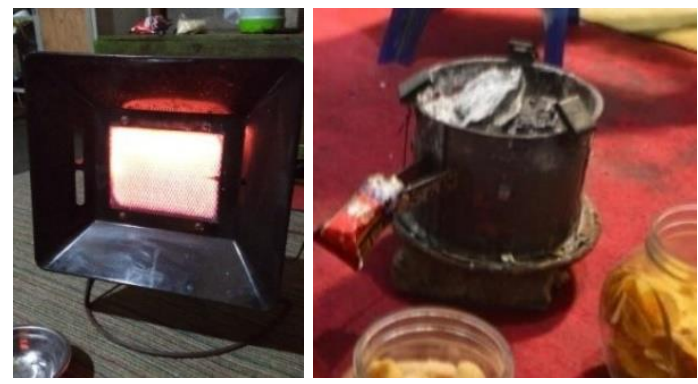

Figure 3. Gas and charcoal fireplaces

Pawon has core furniture other than the furnace such as jengkok or dingklik used in sitting and gathering. It is a short chair made of wood and replaced with a small plastic chair during development due to the ease with which it can be obtained.

1. A fireplace is a key element of the house in Karangtengah hamlet settlement

All the houses in Karangtengah Hamlet have a fireplace regardless of the type of material used for the walls as observed with those with or without plaster as well as those made with wooden materials. Most of the houses have tin roofs but some have roof tiles or tassels. According to an informant, Mr. Ino, when building a house in the past, a fireplace and one bedroom are usually prioritized. Moreover, the construction of residential houses used to take time due to the stages involved. The fireplace room also known as pawon is an important element to provide food which is an energy source and also serves as a place for most of the residents' activities. It is currently an important element of the community life in Karangtengah Hamlet. Mr. Tono, a 28 years old informant, reported the fireplace to be the main element supporting human activities and always found in newly built residences. Ancient houses also maintain a fireplace and this means it is a key element of the houses in Karangtengah hamlet settlement. A type of these houses is shown in figure 4.

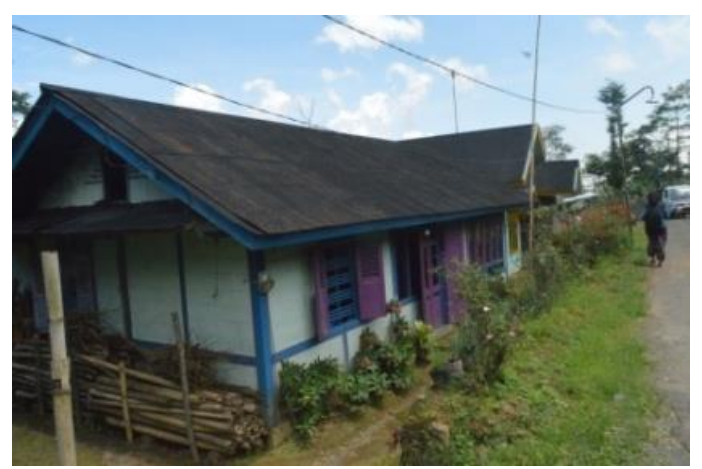

Figure 4. One type of house in Karangtengah Hamlet

The houses in Karangtengah Hamlet are still being constructed through traditional methods. This involves calculating the Javanese day of the house owner's birth also known as the Weton which is usually the husband's day for married people. This is different for unmarried homeowners and this indicates Weton is used in calculating several activities such as the first good day of building a house and the direction towards the main and pawon doors. The use of these Javanese calculations is accompanied by Islamic religious beliefs such as not turning back against the Qibla direction when constructing a pawon. The integration of religion in the construction of houses was also reported in Dewa Kaenbaun (Purbadi, Djunaedi, and Sudaryono 2019). Moreover, the house construction in Karangtengah Hamlet usually starts with selametan (thanksgiving) attended by neighbors. It involves eating red porridge together as a symbol of fertility and safety. The application of tradition is currently being applied by the Bugis people (Hatta and Sudrajat 2020) and this provides a sacred value for pawon in the life of the people of Karangtengah Hamlet. One of the informants, Mbah Suprapto, is shown in figure 5 to be explaining the calculation process. 


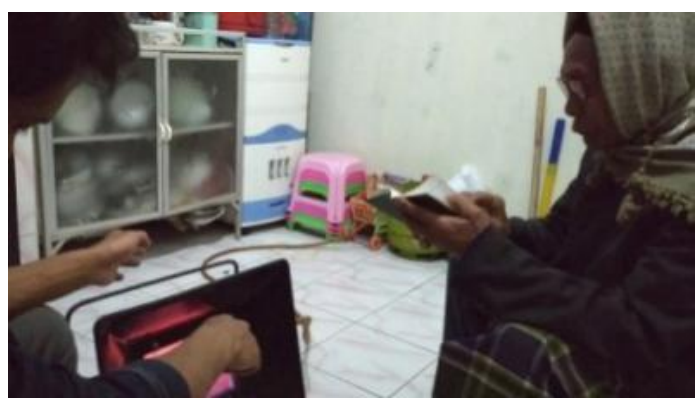

Figure 5. Mbah Suprapto is an expert in Javanese calculations

Pawon is also used as a location to plant newborns' ari-ari (placenta) through an activity known as mendem ari-ari or ngarung ari-ari. The selection of this area is based on the belief that the ari-ari is guarded by the fire in the pawon and that the residents would leave the village or land of birth one day. Mr. Tardi, aged 62 years, reported the tradition of planting placenta to have survived to the present time due to the belief of the residents that it provides safety for the baby until adulthood. The fire keeps the sedulur which is the shadow of the baby whose placenta was planted in pawon. The fireplace was also reported to be used for selametan when an item has just been obtained. This is based on the assumption that the items are durable like fire which never goes out and also serves as a source of light. Meanwhile, the concept of rituals in other traditional houses is also a feature of vernacular dwellings (Prasetyo 2019). Therefore, the traditions and rituals currently being conducted in Karangtengah Hamlet indicate pawon as an important element in people's life from a symbolic aspect.

2. The fireplace is an important point for gathering phenomenon in pawon

The average temperature in Dieng mountains during the day is $18^{\circ} \mathrm{C}$ and the morning air temperature reaches $-5^{\circ} \mathrm{C}$ to $4^{\circ} \mathrm{C}$ during the dry season. Ice flowers also known as "bun upas" by the locals are also seen in the morning and these cold climatic conditions have made residents initiate efforts towards warming up by gathering around the furnace. Mr. Fauzi, one of the informants, said the warmth was accompanied by the gathering activity known as genen which is routinely conducted in the community 2-3 times a day. This is mostly in the morning, afternoon, and evening, especially when the temperature is cold. Most residences use pawon as a gathering place and also to receive guests because the living room is often used as a place to keep motorbikes and store harvest yields or fertilizers. Guests are asked to warm up and drink warm water boiled on the furnace in the pawon. An example of genen activity is shown in figure 6 .

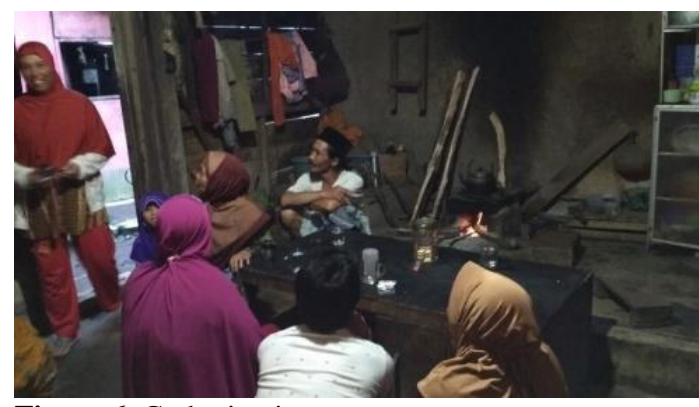

Figure 6. Gathering in pawon

The fireplace is used for heating during ngendong which is an activity where people gather and chat with their neighbors. The furnace is the center of activity due to its heat source and jokes and laughter during this activity show pawon is the most comfortable place to live in the house (figure 7). The activity is also performed in outer space, especially by men or young people. It is, however, not observed every day at the regional level but usually conducted at special events such as the Prophet's birthday with proper coordination and also during sunny weather conditions. According to Mr. Husni, outdoor ngendong usually holds at a road junction or large yard while those performed indoors are mainly attended by family, relatives, and neighbors.

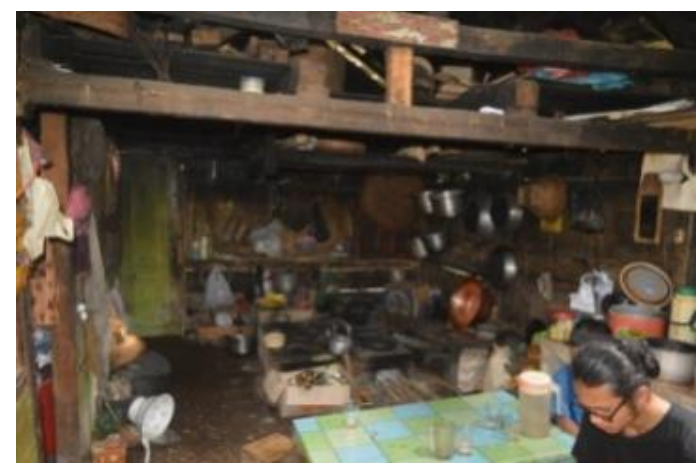

Figure 7. Pawon condition in Karangtengah Hamlet

\section{Fireplaces and kinship}

Kinship around the house is based on one lineage with most of the daily calls found to be between neighbors such as Lek (father/mother's sister), Siwo (father/mother's brother), Mbah (father/mother's parents), and others. The 
majority of the people in Karangtengah are indigenes while only a few are migrants. Moreover, pawon has a special door known as the butulan which is mostly used by visiting neighbors or relatives. The butulan in one house and another are often close together as shown in table 1 and this makes it easier for residents to visit each other. Pawon is also a place to meet guests considered siblings as well as those that became close at the time because of their friendship with one of the residents invited to gather. An example of this is the visitation by the teacher of the homeowner's children.

Table 1. Fireplace connection in the house

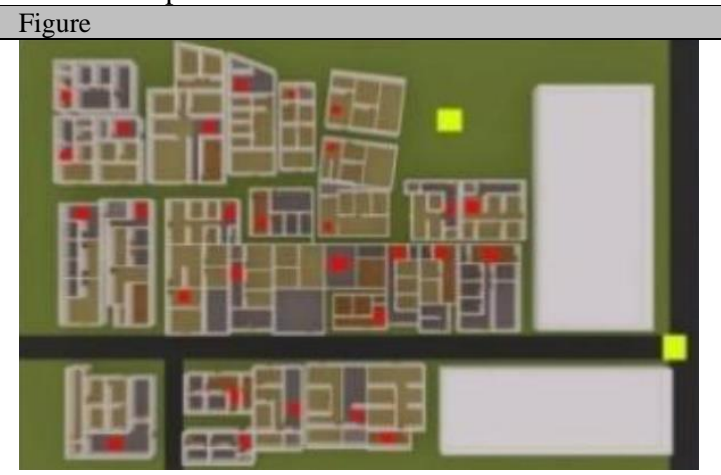

Description

All houses have fireplaces. Location 1 has two outdoor fireplaces formed during major activities such as the Prophet's birthday or other special moments. Desc: Indoor and outdoor fireplace.

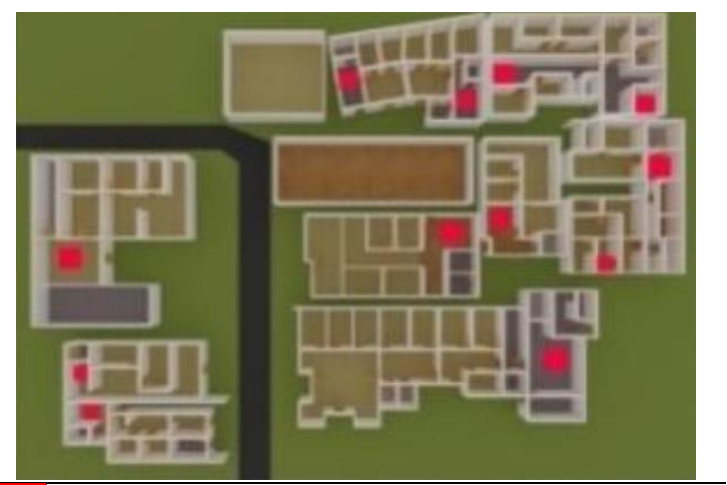

Fireplace

Outdoor fireplace

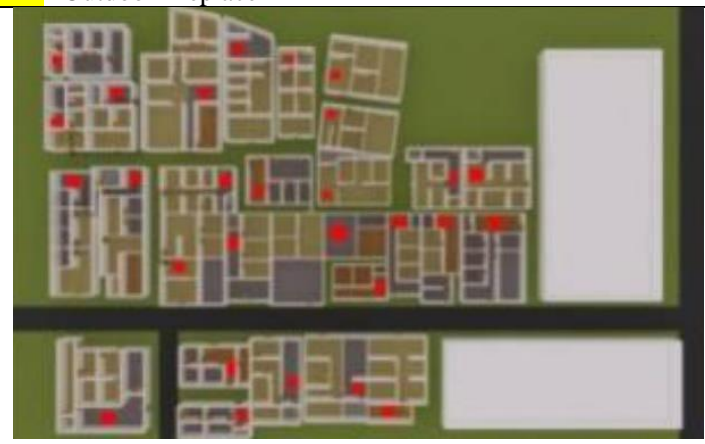

One house has one or two fireplaces which are connected with each other while some others have two. Desc: The connection between the fireplace in one house. 


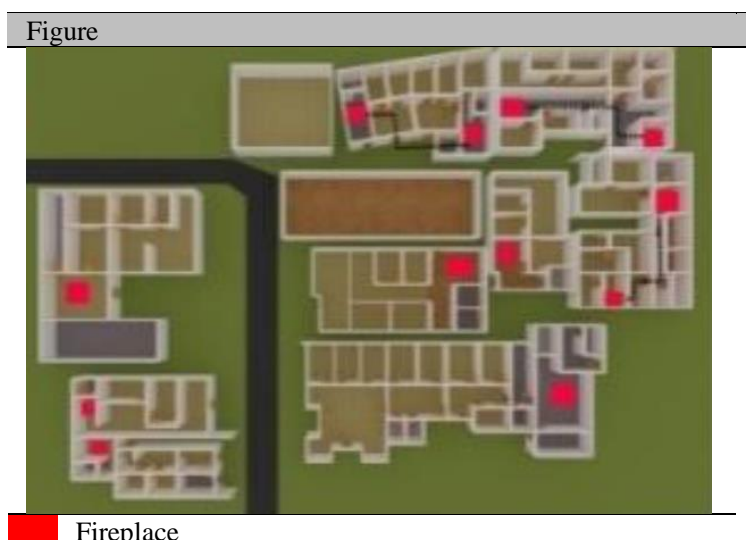

Description

Fireplace

....... Fireplace relationship in one house

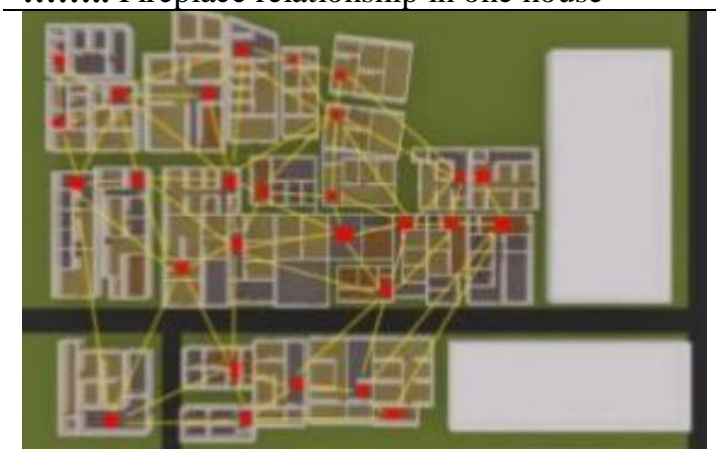

The fireplace between houses is connected by butulan which is the door of the pawon developed based on the closeness and kinship of the homeowner. Desc: The fireplace connection between houses.

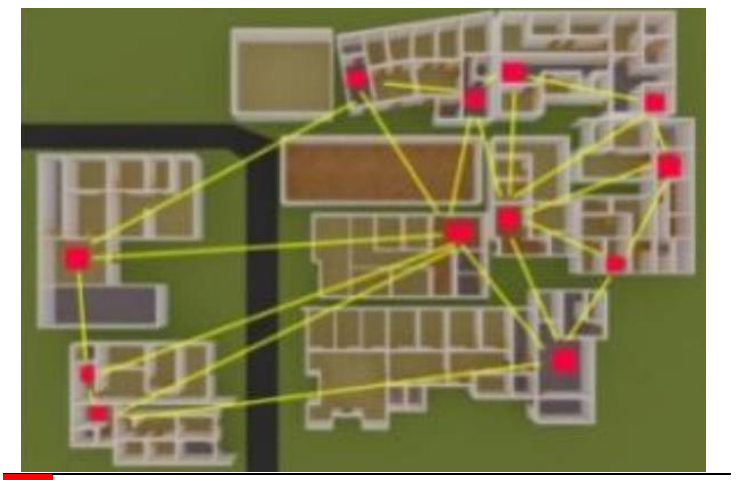

Fireplace

-Fireplace connection between houses 


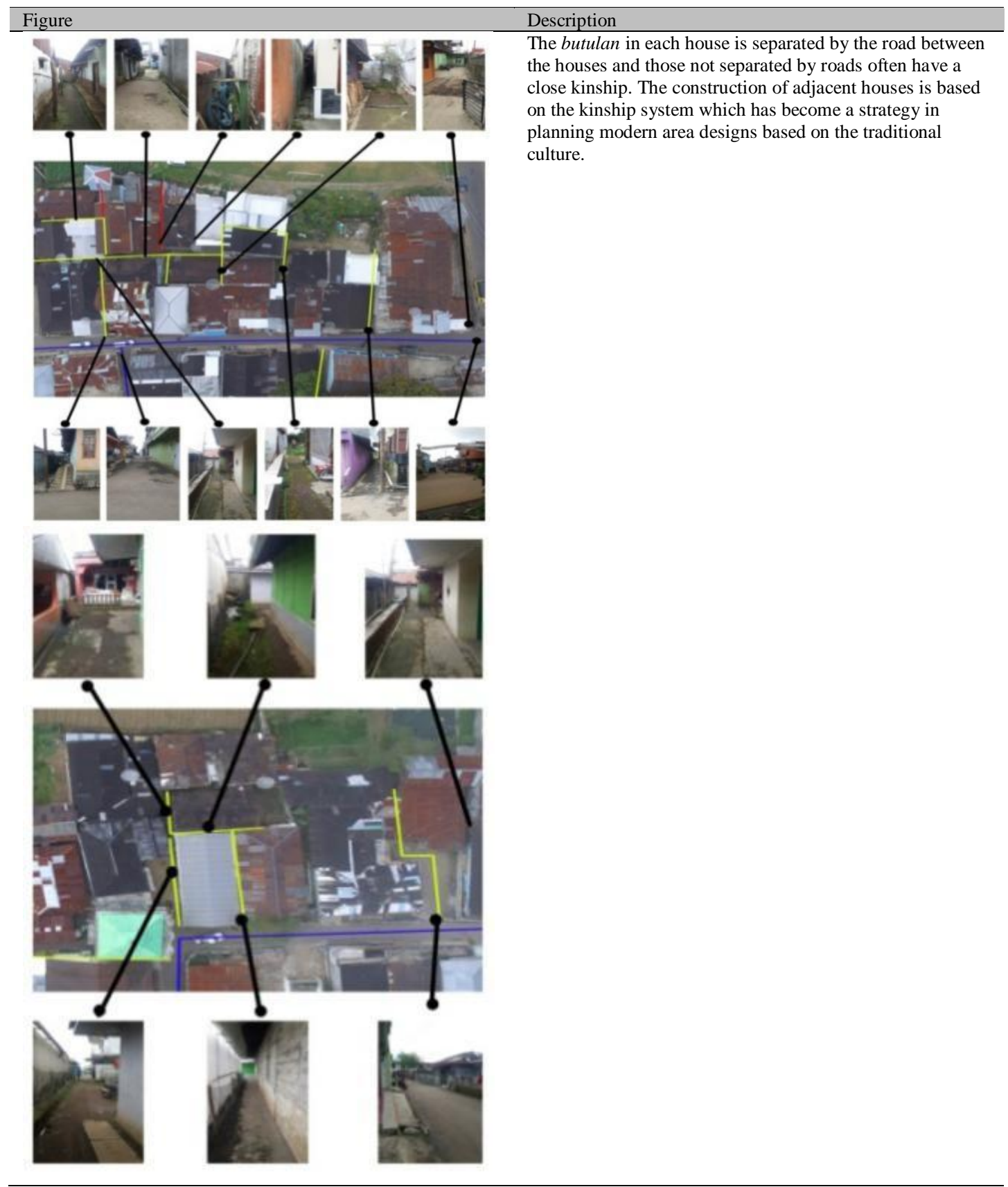

Pawon was observed to have a high hierarchy in Karangtengah Hamlet due to its function as a place to host guests considered to be "sedulur" in the Javanese kinship system. These are respected people without any previous acquaintance with the family. The findings of this study are in accordance with the research conducted by Choi on the socio-culture of individualism-collectivism based on the familiarity factor between the community and foreigners (Choi 2018).
Familiarity has also been observed through the interpretation of different spatial configurations which spatially reflect people's culture (Hermawan, Prijotomo, and Dwisusanto 2020).

Kinship forms the basis of spatial patterns on several locations and the factor affecting those in mountainous areas is the existence of sacred meanings in the arrangement (Agusintadewi 2016). The sacred meaning is in the form of the relationship between humans and their creators 
while kinship is between humans and this was observed to be more than blood relations in the studied area but also includes the intimacy or respect for people's relationship with their family. The concept has become wider with effects on the spatial pattern of houses using fireplaces as the main element.

The kinship system in the spatial pattern of the population was used as a strategy to reduce urbanization and considered applicable in formulating policies related to resettlement. A study was conducted by Doxiadis to determine the appropriate strategy using rural settlements in Zambia as a case study. Moreover, the Central Place Theory discovered by Christaller and the abstract hexagonal geometric models were applied to arrange different sizes of settlements into one space. This was, therefore, considered a standard form of rural settlement to reduce urbanization.

Previous studies on rural settlements have been conducted using quantitative or quantitative methods such as statistical analysis, mapping, field surveys, interviews, and ethnographic data and those with the same method showed different results. There is, however, the need to focus on the economic and political objectives in these studies due to their influence on the conditions of the rural settlements. Moreover, the fluidity and characters of the village depend on land use movements which are strongly associated with the social, economic, and cultural links between the population and use of land to create social and political structures. This means economic, social, and environmental factors are strategies to be used in developing rural settlements. Furthermore, the strong relationship between Anthropos or man, shells, nature, networks, and society is another developmental strategy (Phokaides 2018).

\section{Conclusion}

The spatial pattern in Karangtengah Hamlet was found to be influenced by social, cultural, climatic, topographical, and spiritual factors in line with the findings of previous studies. This means these factors can be used in determining regional development strategies for both urban and rural areas which are affected by the problem of migration due to low growth. Moreover, the spatial patterns in the studied area were determined by the kinship system designed by the original inhabitants and this means there is no much urbanization in the area. Meanwhile, it is possible to use the kinship system strategy as a reference for regional development.

\section{References}

Agusintadewi, Ni Ketut. 2016. 'Pola Spasial Permukiman Tradisional Bali Aga Di Desa Sekardadi, Kintamani'. Review of Urbanism and Architectural Studies 14 (2): 47-57. https://doi.org/10.21776/ub.ruas.2016.014.02. 5.

Al-Sallal, Khaled A. 2001. 'The Balanced Synthesis of Form and Space in the Vernacular House of Sana'a: Bioclimatic and Functional Analysis'. Architectural Science Review $\quad 44 \quad$ (4): $419-28$. https://doi.org/10.1080/00038628.2001.9696 922.

Alkhansari, Maryam Gharavi. 2015. 'Analysis of the Responsive Aspects of the Traditional Persian House'. Journal of Architecture and Urbanism $39 \quad$ (4): 273-89. https://doi.org/10.3846/20297955.2015.1088 414.

Brkanić, Ivana, Dina Stober, and Matej Mihić. 2018. 'A Comparative Analysis of the Spatial Configuration of Apartments Built in Osijek, Croatia, between 1930 and 2015'. Journal of Asian Architecture and Building Engineering $17 \quad$ (1): 23-30. https://doi.org/10.3130/jaabe.17.23.

Choi, Youngjun. 2018. 'Identifying the Individualist / Collectivist Cultural Dimension in Space'. Journal of Asian Architecture and Building Engineering 17 (2): 337-44. https://doi.org/10.3130/jaabe.17.337.

Creswell, John W., and Cheryl N. Poth. 2017. Qualitative Inquiry and Research Design Choosing Among Five Approaches. United Kingdom: SAGE Publications, Inc.

Hatta, Asta Juliarman, and Iwan Sudrajat. 2020. 'Peran Sanro Bola Dalam Tradisi Membangun Rumah Tradisional Bugis Di Kabupaten Soppeng'. ARTEKS : Jurnal Teknik Arsitektur 5 (1): 57-66. https://doi.org/10.30822/arteks.v5i1.119.

Hermawan, Josef Prijotomo, and Yohanes Basuki Dwisusanto. 2020. 'The Geni Tradition as the Center of the Shelter for Plateau Settlements'. 
Ecology, Environment and Conservation 26 (1): 34-38. http://www.envirobiotechjournals.com/article _abstract.php?aid $=10291 \&$ iid $=298 \&$ jid $=3$.

Hosseini Raviz, Seyed Reza, Ali Nik Eteghad, Ezequiel Uson Guardiola, and Antonio Armesto Aira. 2015. 'Flexible Housing: The Role of Spatial Organization in Achieving Functional Efficiency'. International Journal of Architectural Research: ArchNet-IJAR 9 (2): $65 . \quad$ https://doi.org/10.26687/archnetijar.v9i2.422.

Kullmann, Karl. 2016. 'Disciplinary Convergence: Landscape Architecture and the Spatial Design Disciplines'. Journal of Landscape Architecture 11 (1): 30-41. https://doi.org/10.1080/18626033.2016.1144 668.

Markevičiené, Jūratè. 2012. 'The Spirit of The Place - The Problem of (Re)Creating/Vietos Dvasios Kūrimo (Atkūrimo) Problema'. Journal of Architecture and Urbanism 36 (1): 73-81.

https://doi.org/10.3846/20297955.2012.6797 89.

Pant, Mohan, and Shuji Funo. 2004. 'A Study on the Pattern of Plot Divisions of Courtyard Residential Blocks of Patan, Kathmandu Valley'. Journal of Asian Architecture and Building Engineering 3 (1): 197-205. https://doi.org/10.3130/jaabe.3.197.

Phokaides, Petros. 2018. 'Rural Networks and Planned Communities: Doxiadis Associates' Plans for Rural Settlements in PostIndependence Zambia'. The Journal of Architecture 23 (3): 471-97. https://doi.org/10.1080/13602365.2018.1458 044.

Prasetyo, V. F. Agung Langgeng. 2019. 'Tradisi Pada Rumah Adat Suku Ngalum Ok Di Era Modernisasi'. ARTEKS: Jurnal Teknik
Arsitektur $3 \quad$ (2): $187-98$. https://doi.org/10.30822/arteks.v3i2.69.

Purbadi, Yohanes Djarot, Achmad Djunaedi, and Sudaryono. 2019. 'Kearifan Kaenbaun Sebagai Dasar Konseptual Pada Tata Spasial Arsitektur Permukiman Suku Dawan Di Desa Kaenbaun'. ARTEKS: Jurnal Teknik Arsitektur 3 (2): 215-38. https://doi.org/10.30822/arteks.v3i2.71.

Subroto, Tarcicius Yoyok Wahyu. 2019. 'Koeksistensi Alam Dan Budaya Dalam Arsitektur'. ARTEKS: Jurnal Teknik Arsitektur 3 (2). https://doi.org/10.30822/arteks.v3i2.60.

Sudradjat, Iwan. 2020. 'Teori dalam Penelitian Arsitektur'. ARTEKS: Jurnal Teknik Arsitektur 5 (1): $\quad$ i-vi. https://doi.org/10.30822/arteks.v5i1.378.

Thanousorn, Vongpraseuth, and Kiyoaki Oikawa. 2010. 'Spatial Development of Lao Urban Dwellings along the Mekong River'. Journal of Asian Architecture and Building $\begin{array}{llll}\text { Engineering } & 9 & \text { (2): } & \text { 403-7. }\end{array}$ https://doi.org/10.3130/jaabe.9.403.

Wongphyat, Waricha. 2009. 'Spatial Anthropology of Traditional Thai-Islamic Dwellings in Eastern Bangkok'. Journal of Asian Architecture and Building Engineering $8 \quad$ (2): $347-54$. https://doi.org/10.3130/jaabe.8.347.

Yun, Jieheerah. 2016. 'Experiential Analysis of the Vernacular: South Korea's Gudeul System'. Journal of Asian Architecture and Building Engineering 15 (2): 169-75. https://doi.org/10.3130/jaabe.15.169.

Zappulla, Carmelo, Cristian Suau, and Alenka Fikfak. 2014. 'The Pattern Making of MegaSlums on Semantics in Slum Urban Cultures'. Journal of Architecture and Urbanism 38 (4): 247-64.

https://doi.org/10.3846/20297955.2014.9873 68. 